\title{
PENGARUH KEPUTUSAN INVESTASI, KEPUTUSAN PENDANAAN, DAN KEBIJAKAN DEVIDEN TERHADAP NILAI PERUSAHAAN PADA SEKTOR PERKEBUNAN YANG TERDAFTAR DI BURSA EFEK INDONESIA PERIODE 2011-2014
}

\author{
Sindy Dwiroro Pangestu ${ }^{1}$, Yunan Surono ${ }^{2}$
}

\begin{abstract}
The research was done in the agricultural sector listed on the indonesian stock period 2011-2014.The agricultural sector is a company that their activities trying to establish a certain plants on land or media all other plants.The agricultural sector listed on the efek indonesia which is there are 16 company where who was elected to the sample is purposive sampling, then become a sample in this research was as much as 4 companies are as follows: PT. Astra Argo Lestari Tbk, PT. Jaya Agra Wattie Tbk, PT. PP London Sumatra Indonesia Tbk, and PT. Salim Ivomas Pratama Tbk. The methodology be done in descriptive analysis and use the regression analysis multiple linear using spss 22 and statistic asumsition clasic test. The done is the hypothesis $F$ test and the $t$ test. and know to determine how much the determination $\left(R^{2}\right)$. Based on the results of this research suggests that in simultan between Return On Assets (ROA), Debt Asset Ratio (DAR) and Dividends Payout Ratio (DPR) significant Price Book Value (PBV) because f test larger than $f$ tabel of $18,190>3,49$ and the standard significant numbers (sig) of $0,000<0,05$ so that it can be said to exist a positive influence. While in partial only Dividend Payout Ratio (DPR) that influence the Price Book Value (PBV) because $t$ test greater than $t$ table of $2,798>2,179$. The value of the determination $\left(R^{2}\right)$ of $82 \%$ influenced by Return On Assets (ROA), Debt Asset Ratio (DAR), and Devidend Payout Ratio (DPR) the dominant significant Price Book Value (PBV) of $18 \%$ influenced by other factor. And only Dividend Payout Ratio (DPR) a variable dominant significant Price Book Value (PBV) as much as 2,798 >2,179. So $H_{o}$ been denied and $H_{a}$ accepted, it means have had a positive impact significantly on variables Price Book Value $(P B V)$ in the agricultural sector listed on the efek indonesia the period 2011 -2014.
\end{abstract}

Keywords: an investment decision, the funding, dividend policy, and value of enterprise.

\section{PENDAHULUAN}

Perusahaan merupakan suatu wadah yang terdiri dari sekumpulan manusia yang bekerja secara bersama-sama untuk menjalankan fungsi manajemen, yaitu manajemen sumber daya manusia, manajemen keuangan, manajemen produksi operasional, dan manajemen pemasaran. Perusahaan yang ingin mencapai tujuan jangka panjang, akan mengambil beberapa keputusan berupa keputusan investasi, kebijakan deviden serta keputusan pendanaan (Husnan dan Pudjiastuti, 2006:5). Ketiga keputusan keuangan tersebut merupakan keputusan yang saling berkaitan satu sama lainnya serta mempengaruhi nilai perusahaan.

Nilai perusahaan yang optimal akan dicapai dengan mengkombinasikan fungsi-fungsi dari manajemen keuangan yang lainnya, sehingga nantinya akan berdampak pula terhadap nilai perusahaan (Rohman, 2012). Faktor-faktor yang

\footnotetext{
${ }^{1}$ Mahasiswa Fakultas Ekonomi Universitas Batanghari

${ }^{2}$ Dosen Fakultas Ekonomi Universitas Batanghari
} 
mempengaruhi nilai perusahaan terdiri dari keputusan investasi, kebijakan deviden serta keputusan pendanaan.

Pada data di bawah ini dapat terlihat mengenai data yang menunujukkan kondisi Perkembangan Return on Asset (ROA) dan Debt to Asset Ratio (DAR) pada Sektor Perkebunan yang terdaftar di BEI pada periode 2011-2014 sebagai berikut :

Tabel 1.1

Perembangan ROA (Dalam Persentase) dan DAR (Dalam Kali) pada Sektor Perkebunan yang terdaftar BEI periode 2011-2014

\begin{tabular}{|c|c|c|c|c|}
\hline$\underline{\text { Tahun }}$ & $\frac{\text { Keputusan }}{\frac{\text { Investasi }}{\underline{\text { ROA })}}}$ & $\frac{\text { Perkembangan }}{\underline{(\%)}}$ & $\frac{\frac{\text { Keputusan }}{\text { Pendanaan }}}{\underline{\text { (DAR) }}}$ & $\frac{\text { Perkembangan }}{\underline{(\%)}}$ \\
\hline \multicolumn{5}{|c|}{ Astra Argo Lestari (AALI) } \\
\hline 2011 & 24,48 & - & 0,17 & - \\
\hline 2012 & 20,29 & $(17,11)$ & 0,25 & 47,5 \\
\hline 2013 & 12,72 & $(37,30)$ & 0,31 & 19,35 \\
\hline 2014 & 14,12 & 11,01 & 0,36 & 16,12 \\
\hline$\underline{\text { Rata-rata }}$ & 17,90 & $(14,46)$ & 0,27 & 27,51 \\
\hline \multicolumn{5}{|c|}{$\overline{\text { Eagle High Plantation (BWPT) }}$} \\
\hline 2011 & 8,93 & - & 0,60 & - \\
\hline 2012 & 5,34 & $(40,20)$ & 0,66 & 10 \\
\hline 2013 & 2,93 & $(45,13)$ & 0,65 & $(1,51)$ \\
\hline 2014 & 1,19 & $(59,38)$ & 0,58 & $(10,76)$ \\
\hline Rata-rata & 4,60 & $(48,23)$ & 0,62 & $(0,75)$ \\
\hline \multicolumn{5}{|c|}{ Gozco Plantations (GZCO) } \\
\hline 2011 & 5,93 & - & 0,47 & - \\
\hline 2012 & 3,09 & $(47,89)$ & 0,50 & 6,4 \\
\hline 2013 & $-2,99$ & $(196,76)$ & 0,53 & 6 \\
\hline 2014 & 1,58 & $(152,84)$ & 0,52 & $(1,8)$ \\
\hline$\underline{\text { Rata-rata }}$ & 1,90 & $(132,49)$ & 0,51 & 3,53 \\
\hline \multicolumn{5}{|c|}{ Jaya Arga Wattie (JAWA) } \\
\hline 2011 & 9,55 & - & 0,42 & - \\
\hline 2012 & 6,86 & $(28,17)$ & 0,44 & 4,76 \\
\hline 2013 & 2,63 & $(61,66)$ & 0,52 & 18,18 \\
\hline 2014 & 1,69 & $(35,74)$ & 0,57 & 9,61 \\
\hline Rata-rata & 5,18 & $(41,85)$ & 0,49 & 10,85 \\
\hline \multicolumn{5}{|c|}{ PP London Sumatra Indonesia (LSIP) } \\
\hline 2011 & 25,05 & & 0,14 & - \\
\hline 2012 & 14,77 & $(41,03)$ & 0,17 & 21,42 \\
\hline 2013 & 9,64 & $(34,73)$ & 0,17 & 0 \\
\hline 2014 & 10,59 & 9,85 & 0,17 & 0 \\
\hline$\underline{\text { Rata-rata }}$ & 12,37 & $(7,76)$ & 0,16 & 7,14 \\
\hline \multicolumn{5}{|c|}{ Sampoerna Argo (SGRO) } \\
\hline 2011 & 16,11 & - & 0,27 & - \\
\hline 2012 & 8,13 & $(49,53)$ & 0,36 & 33,33 \\
\hline 2013 & 2,67 & $(67,15)$ & 0,40 & 11,11 \\
\hline 2014 & 6,40 & 139,70 & 0,45 & 12,50 \\
\hline$\underline{\text { Rata-rata }}$ & 8,33 & 7,67 & 0,37 & 18,98 \\
\hline \multicolumn{5}{|c|}{$\underline{\text { Salim Ivomas Pratama (SIMP) }}$} \\
\hline 2011 & 11,38 & - & 0,41 & - \\
\hline 2012 & 5,71 & $(49,82)$ & 0,39 & $(4,87)$ \\
\hline 2013 & 2,26 & $(60,40)$ & 0,43 & 10,25 \\
\hline 2014 & 3,58 & 58,40 & 0,46 & 6,97 \\
\hline Rata-rata & 5,73 & $(17,27)$ & 0,42 & 4,11 \\
\hline \multicolumn{5}{|c|}{ Smart (SMAR) } \\
\hline 2011 & 12,71 & - & 0,50 & - \\
\hline
\end{tabular}




\begin{tabular}{|c|c|c|c|c|}
\hline 2012 & 13,25 & 4,24 & 0,45 & (10) \\
\hline 2013 & 4,86 & $(63,32)$ & 0,65 & 44,44 \\
\hline 2014 & 6,93 & 42,59 & 0,63 & 3,07 \\
\hline Rata-rata & 9,44 & $(5,49)$ & 0,56 & 10,45 \\
\hline \multicolumn{5}{|c|}{ Tunas Baru Lampung (TBLA) } \\
\hline 2011 & 10,32 & - & 0,62 & - \\
\hline 2012 & 4,69 & $(54,55)$ & 0,66 & 6,45 \\
\hline 2013 & 1,39 & $(70,36)$ & 0,71 & 7,57 \\
\hline 2014 & 5,96 & 328,77 & 0,66 & $(7,04)$ \\
\hline$\underline{\text { Rata-rata }}$ & 5,59 & 67,95 & 0,66 & 4,45 \\
\hline \multicolumn{5}{|c|}{ Bakrie Sumatera Plantation (UNSP) } \\
\hline 2011 & 3,90 & - & 0,54 & - \\
\hline 2012 & 3,99 & 2,31 & 0,52 & $(3,70)$ \\
\hline 2013 & $-5,62$ & $(240,85)$ & 0,58 & 11,53 \\
\hline 2014 & $-15,36$ & 173,31 & 0,73 & 25,86 \\
\hline$\underline{\text { Rata-rata }}$ & $-3,30$ & $(21,74)$ & 0,59 & 11,23 \\
\hline \multicolumn{5}{|c|}{ Multi Agro Gemilang Plantation (MAGP) } \\
\hline 2011 & - & - & - & - \\
\hline 2012 & - & - & - & - \\
\hline 2013 & - & - & 0,23 & - \\
\hline 2014 & 0,01 & - & 0,26 & 13,04 \\
\hline$\underline{\text { Rata-rata }}$ & 0,01 & - & 0,25 & 13,04 \\
\hline \multicolumn{5}{|c|}{ Golden Plantation (GOLL) } \\
\hline 2011 & - & - & - & - \\
\hline 2012 & - & - & - & - \\
\hline 2013 & - & - & - & - \\
\hline 2014 & 0,35 & - & 0,53 & - \\
\hline$\underline{\text { Rata-rata }}$ & 0,35 & - & 0,53 & - \\
\hline \multicolumn{5}{|c|}{ Dharma Satya Nusantara (DSNG) } \\
\hline 2011 & - & - & - & - \\
\hline 2012 & - & - & - & - \\
\hline 2013 & 3,64 & - & 0,72 & - \\
\hline 2014 & 9,06 & 148,90 & 0,68 & $(2,88)$ \\
\hline$\underline{\text { Rata-rata }}$ & 6,35 & 148,90 & 0,7 & $(2,88)$ \\
\hline \multicolumn{5}{|c|}{ Austindo Nusantara Jaya (ANJT) } \\
\hline 2011 & - & - & - & - \\
\hline 2012 & - & - & - & - \\
\hline 2013 & 0,09 & - & 0,08 & - \\
\hline 2014 & 0,18 & 1 & 0,15 & 87,5 \\
\hline$\underline{\text { Rata-rata }}$ & 0,14 & 1 & 0,12 & 87,5 \\
\hline \multicolumn{5}{|c|}{ Provident Agro (PALM) } \\
\hline 2011 & - & - & - & - \\
\hline 2012 & $-2,64$ & 295,83 & 0,73 & - \\
\hline 2013 & $-10,45$ & $(138,08)$ & 0,61 & $(16,43)$ \\
\hline 2014 & 3,98 & 0,78 & 0,60 & $(1,63)$ \\
\hline$\underline{\text { Rata-rata }}$ & $-3,04$ & 52,84 & 0,65 & $(9,03)$ \\
\hline \multicolumn{5}{|c|}{$\overline{\text { Sawit Sumbermas Sarana (SSMS) }}$} \\
\hline 2011 & - & - & - & - \\
\hline 2012 & 26,58 & - & 0,78 & - \\
\hline 2013 & 17,06 & $(35,81)$ & 0,37 & $(52,56)$ \\
\hline 2014 & 18,30 & 7,26 & 0,25 & $(32,43)$ \\
\hline Rata-rata & 20,65 & $(9,51)$ & 0,47 & $(28,33)$ \\
\hline
\end{tabular}

\section{Sumber : IDX. co.id tahun 2011 - 2014}

Pada data di bawah ini dapat terlihat mengenai data yang menunujukkan kondisi Perkembangan Deviden (DPR) dan Price Book Value (PBV) pada Sektor Perkebunan yang terdaftar di BEI pada periode 2011-2014 sebagai berikut : 
Tabel 1.2

Perkembangan DPR (Dalam Jutaan Rupiah) dan PBV (Dalam Bentuk Kali) pada Sektor Perkebunan yang terdaftar di BEI periode 2011-2014

\begin{tabular}{|c|c|c|c|c|}
\hline$\underline{\text { Tahun }}$ & $\frac{\text { Kebijakan }}{\frac{\text { Deviden }}{(\text { DPR })}}$ & $\frac{\text { Perkembangan }}{(\%)}$ & $\frac{\stackrel{\text { Nilai }}{\text { Perusahaan }}}{(\text { PBV })}$ & $\frac{\text { Perkembangan }}{(\%)}$ \\
\hline \multicolumn{5}{|c|}{ Astra Argo Lestari (AALI) } \\
\hline 2011 & 995,00 & - & 4,06 & - \\
\hline 2012 & 685,00 & $(31,15)$ & 3,31 & $(18,47)$ \\
\hline 2013 & 675,00 & $(1,45)$ & 3,85 & 16,31 \\
\hline 2014 & 960,00 & 2,85 & 3,41 & $(11,42)$ \\
\hline$\underline{\text { Rata-rata }}$ & 828,75 & $(9,91)$ & 3,65 & $(4,53)$ \\
\hline \multicolumn{5}{|c|}{$\overline{\text { Eagle High Plantation (BWPT) }}$} \\
\hline 2011 & 12,00 & - & 3,17 & - \\
\hline 2012 & 12,00 & 0 & 3,36 & 5,99 \\
\hline 2013 & 6,00 & $(50)$ & 2,64 & $(21,42)$ \\
\hline 2014 & - & - & 5,33 & 101,89 \\
\hline$\underline{\text { Rata-rata }}$ & 10,00 & $(25)$ & 3,62 & 28,82 \\
\hline \multicolumn{5}{|c|}{ Gozco Plantations (GZCO) } \\
\hline 2011 & 1,00 & - & 0,88 & - \\
\hline 2012 & - & - & 0,92 & 4,54 \\
\hline 2013 & - & - & 0,44 & $(52,17)$ \\
\hline 2014 & - & - & 0,53 & 20,45 \\
\hline$\underline{\text { Rata-rata }}$ & 1,00 & - & 0,69 & $(9,06)$ \\
\hline \multicolumn{5}{|c|}{ Jaya Arga Wattie (JAWA) } \\
\hline 2011 & 9,60 & - & 1,26 & - \\
\hline 2012 & 11,96 & 24,58 & 1,14 & $(9,52)$ \\
\hline 2013 & 1,80 & $(84,94)$ & 1,13 & $(0,87)$ \\
\hline 2014 & 1,34 & $(25,55)$ & 1,06 & $(6,19)$ \\
\hline$\underline{\text { Rata-rata }}$ & 6,17 & $(28,63)$ & 1,15 & $(5,52)$ \\
\hline \multicolumn{5}{|c|}{ PP London Sumatra Indonesia (LSIP) } \\
\hline 2011 & 100,00 & - & 2,63 & - \\
\hline 2012 & 66,00 & (34) & 2,50 & $(4,94)$ \\
\hline 2013 & 46,00 & $(30,30)$ & 1,99 & $(20,4)$ \\
\hline 2014 & 53.00 & 15,21 & 1,84 & $(7,53)$ \\
\hline$\underline{\text { Rata-rata }}$ & 66,25 & $(16,36)$ & 2,24 & $(10,95)$ \\
\hline \multicolumn{5}{|c|}{ Sampoerna Argo (SGRO) } \\
\hline 2011 & 87,30 & - & 2,25 & - \\
\hline 2012 & 45,00 & $(48,45)$ & 2,26 & 0,44 \\
\hline 2013 & 15,00 & $(66,66)$ & 1,40 & $(38,05)$ \\
\hline 2014 & - & - & 1,33 & (5) \\
\hline$\underline{\text { Rata-rata }}$ & 49,1 & $(57,55)$ & 1,81 & $(14,20)$ \\
\hline \multicolumn{5}{|c|}{ Salim Ivomas Pratama (SIMP) } \\
\hline 2011 & 21,00 & - & 1,20 & - \\
\hline 2012 & 22,00 & 4,76 & 1,13 & $(5,83)$ \\
\hline 2013 & 10,00 & $(54,54)$ & 0,77 & $(31,85)$ \\
\hline 2014 & 16,00 & 37,5 & 0,68 & $(11,68)$ \\
\hline$\underline{\text { Rata-rata }}$ & 17,25 & $(4,09)$ & 0,94 & $(16,45)$ \\
\hline \multicolumn{5}{|c|}{ Smart (SMAR) } \\
\hline 2011 & 200,00 & - & 2,51 & - \\
\hline 2012 & $1.200,00$ & 500 & 2,24 & $(10,75)$ \\
\hline 2013 & 5,00 & $(99,58)$ & 3,48 & 55,35 \\
\hline 2014 & - & - & 3,04 & $(12,64)$ \\
\hline$\underline{\text { Rata-rata }}$ & 468,33 & 200,21 & 2,81 & 10,65 \\
\hline \multicolumn{5}{|c|}{ Tunas Baru Lampung (TBLA) } \\
\hline 2011 & 26,50 & - & 1,81 & - \\
\hline 2012 & 15,00 & $(43,39)$ & 1,43 & $(20,99)$ \\
\hline 2013 & 19,00 & 26,66 & 1,29 & $(9,79)$ \\
\hline
\end{tabular}


2014

Rata-rata

Bakrie S

2011

2012

2013

2014

Rata-rata

Multi Agro Gemilang Plantation (MAGP)

2011

2012

2013

2014

$\underline{\text { Rata-rata }}$

Golden Plantation (GOLL)

2011

2012

2013

2014

Rata-rata

Dharma Satya Nusantara (DSNG)

2011

2012

2013

2014

$$
20
$$

50

Rata-rata

35

Austindo Nusantara Jaya (ANJT)

$$
2011
$$

2012

2013

2014

Rata-rata

Provident Agro (PALM)

2011

2012

2013

2014

Rata-rata

$\underline{\text { Sawit Sumbermas Sarana (SSMS) }}$

\begin{tabular}{cc}
2011 & - \\
2012 & - \\
2013 & - \\
2014 & 22,65 \\
Rata-rata & 22,65 \\
\hline
\end{tabular}

1,95

1,62

0,43

0,16

0,14

0,14

0,21

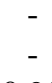

0,95

0,49

0,72

-
-
-
1,31
1,31

2,59

3,78

3,19

150

150

-
0
0

1,11

0,96

1,04

2,60

1,64

1,97

2,07

3,37

5,78

4,58
$(48,42)$

$(48,42)$

51,16

6,79

$(62,79)$

$(12,5)$

0
$25,09)$

$(25,09)$

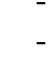

$-$

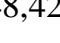

45,94

45,94

$(13,51)$

$(36,92)$

20,12

$(8,4)$

$(8,4)$

71,51

71,51

\section{Sumber : IDX. co.id tahun 2011 - 2014}

Dari latar belakang di atas, maka dapat diidentifikasikan masalah sebagai berikut: 1) Perkembangan ROA pada sektor perkebunan di Bursa Efek Indonesia selama periode 2011 - 2014 berfluktuasi menggambarkan efektivitas pengelolaan asset sehingga di identifikasikan dapat mempengaruhi nilai perusahaan. 2) Perkembangan DAR pada sektor perkebunan di Bursa Efek Indonesia selama periode 2011 - 2014 berfluktuasi menggambarkan efisiensi pembiayaan investasi melalui hutang sehingga di identifikasikan dapat mempengaruhi nilai perusahaan. 3) Perkembangan DPR pada sektor perkebunan di Bursa Efek Indonesia selama periode 2011 - 2014 berfluktuasi menggambarkan deviden yang dapat diterima pemegang saham sehingga dapat mempengaruhi nilai perusahaan. 4) 
Perkembangan PBV pada sektor perkebunan di Bursa Efek Indonesia selama periode 2011 - 2014 berpengaruh terhadap perkembangan Keputusan Investasi, Keputusan Pendanaan, dan Kebijakan Deviden.

Berdasarkan uraian di atas, maka rumusan permasalahan yang akan diteliti dalam penelitian ini adalah sebagai berikut : 1) Bagaimana pengaruh keputusan investasi, keputusan pendanaan dan kebijakan deviden secara simultan dan parsial terhadap nilai perusahaan? 2) Variabel manakah yang dominan berpengaruh terhadap nilai perusahaan?

Berdasarkan perumusan masalah, tujuan yang ingin di capai dalam penelitian ini adalah : 1) Untuk mengetahui pengaruh keputusan investasi, keputusan pendanaan dan kebijakan deviden secara simultan dan parsial terhadap nilai perusahaan. 2) Untuk mengetahui variabel manakah yang dominan berpengaruh terhadap nilai perusahaan.

\section{Keputusan Investasi}

\section{LANDASAN TEORI}

Keputusan investasi yang dibuat perusahaan dipengaruhi oleh kemampuan perusahaan menghasilkan kas yang dapat memenuhi kebutuhan jangka panjang maupun jangka pendek atau yang disebut likuiditas perusahaan. Perusahaan harus menjaga likuiditas agar tidak terganggu, sehingga tidak menganggu kelancaran aktivitas perusahaan untuk melakukan investasi dan tidak kehilangan kepercayaan diri daripihak luar (Hidayat, 2010: 462).

Indikator untuk mengukur keputusan investasi adalah Return on Asset (ROA). Hanafi (2011:42) menyebutkan Return on Asset (ROA) adalah mengukur kemampuan perusahaan menghasilkan laba bersih berdasarkan tingkat aset tertentu. Sedangkan menurut (Fahmi, 2012: 98) Return on Asset merupakan rasio profitabilitas yang dapat menunjukkan kemampuan perusahaan dan membantu investor dalam pengambilan keputusan investasinya. Tingkat Return on Asset yang tinggi dapat diartikan bahwa perusahaan memberdayakan assetnya sekaligus efisiensi operasi perusahaan dapat tercapai. Sebaliknya tingkat Return on Asset yang rendah menunjukkan bahwa perusahaan yang tidak efisien dan tidak berhasil memberdayakan assetnya untuk memperoleh profit. Rumus menghitung ROA sebagai berikut:

Laba bersih

$$
\text { ROA }=\frac{\text { Total Aktiva }}{\text { x } 100 \%}
$$

\section{Keputusan Pendanaan}

Keputusan pendanaan mengindikasikan bagaimana perusahaan membiayai kegiatan operasionalnya atau bagaimana perusahaan membiayai aktivanya. Struktur finansial mencerminkan cara bagaimana aktiva-aktiva perusahaan dibelanjai, dengan demikian struktur finansial tercermin pada keseluruhan pasiva dalam neraca. Struktur finansial mencerminkan perimbangan antara keseluruhan modal asing (hutang) dengan modal sendiri (ekuitas).

Indikator untuk menilai keputusan pendanaan adalah Debt to Asset Ratio (DAR). Pawestri (2006: 164) menyebutkan bahwa keputusan pendanaan dapat diukur melalui Debt Asset Ratio yang meruapakan persentase laba yang dibayarkan kepada para pemegang saham. Dimana rasio ini disebut juga sebagai rasio yang melihat perbandingan hutang perusahaan, yaitu diperoleh 
dari perbandingan total hutang dibagi dengan total aktiva. Rumus menghitung DAR sebagai berikut :

$$
\text { DAR }=\frac{\text { Total Hutang }}{\text { Total Aktiva }} \times 100 \%
$$

\section{Kebijakan Deviden}

Kebijakan deviden menyangkut tentang keputusan untuk membagikan laba yang diperoleh perusahaan kepada pemegang saham dalam bentuk deviden atau laba ditahan guna pembelanjaan investasi dimasa mendatang. Kebijakan deviden merupakan keputusan pembayaran deviden yang mempertimbangkan maksimalisasi harga saham saat ini dan periode mendatang.

DPR banyak digunakan dalam penilaian sebagai cara pengistimasian deviden untuk periode yang akan datang. Menurut Baridwan (2004: 444) rumus yang digunakan untuk menghitung DPR :

Deviden Per lembar saham

$$
\begin{aligned}
& \mathrm{DPR}=\longrightarrow \times 100 \% \\
& \text { Laba perlembar saham }
\end{aligned}
$$

\section{Nilai Perusahaan}

Nilai perusahaan adalah sangat penting karena dengan nilai perusahaan yang tinggi akan diikuti oleh tingginya kemakmuran pemegang saham (Gapensi, 2006). Semakin tinggi harga saham semakin tinggi nilai perusahaan.

Indikator yang mempengaruhi nilai perusahaan yaitu PBV (Price Book Value). Menurut Brigham (2009:92) PBV adalah rasio mengukur nilai yang diberikan pasar keuangan kepada manajemen dan organisasi perusahaan sebagai sebuah perusahaan yang terus tumbuh. Rumus yang digunakan adalah : Harga pasar perlembar saham

$\mathrm{PBV}=\overline{\text { Nilai buku perlembar saham }}$

PBV yang tinggi bisa jadi disebabkan oleh harga pasar yang sudah terlampau tinggi, PBV rendah sering dijadikan indikator mencari saham yang murah.

\section{Kerangka Pemikiran}

\section{METODE PENELITIAN}

Nilai perusahaan dapat dicapai melalui pelaksanaan fungsi manajemen keuangan, dimana satu keputusan keuangan yang diambil akan mempengaruhi keputusan keuangan lainnya dan berdampak pada nilai perusahaan Manajemen keuangan menyangkut penyelesaian atas keputusan penting yang diambil perusahaan, antara lain keputusan investasi, keputusan pendanaan, dan kebijakan deviden. Bahwa keputusan investasi, keputusan pendanaan dan kebijakan deviden berpengaruh positif terhadap nilai perusahaan. Dari rumusan masalah yang terjadi maka dapat dirumuskan kerangka teoritis seagai acuan dalam penelitian sebagai berikut: 


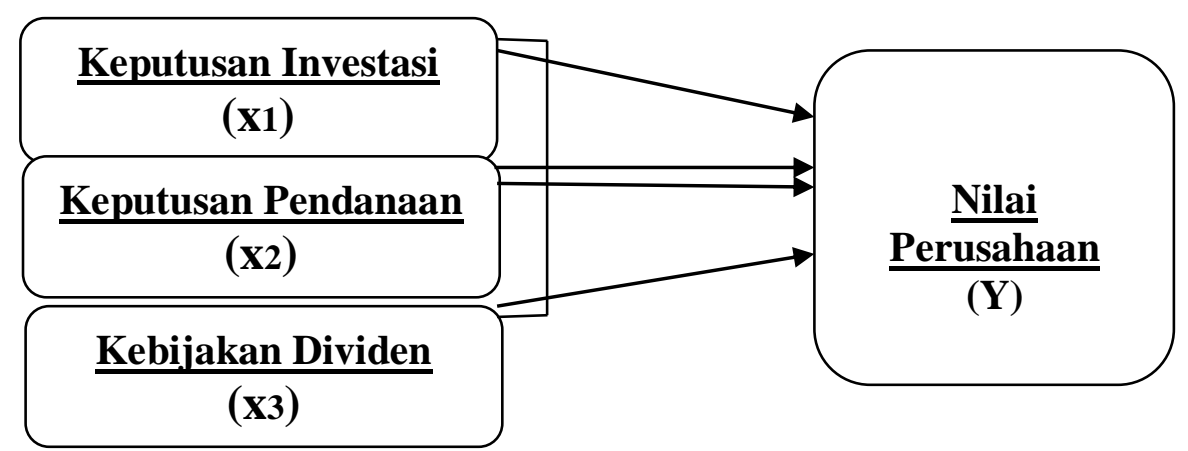

\section{Gambar 1.1 \\ Kerangka Pemikiran}

\section{Populasi dan Sampel}

Populasi adalah jumlah seluruh obyek yang karakteristiknya hendak diduga. Populasi dari penelitian ini adalah perusahaan-perusahaan sektor perkebunan yang terdaftar di Bursa Efek Indonesia (BEI) mencakup periode 2011 - 2014 sebanyak 16 perusahaan.

Pemilihan sampel dilakukan dengan menggunakan purposive sampling yaitu sampel dipilih berdasarkan kriteria-kriteria tertentu, dengan tujuan agar diperoleh sampel yang representatif dengan penelitian yang dilakukan. Adapun kriteria yang dalam pengambilan sampel adalah sebagai berikut :

a. Perusahaan sektor perkebunan yang memiliki laporan keuangan periode $2011-2014$.

b. Emiten memiliki informasi tentang harga saham (closing price) per tahun serta memiliki data rasio keuangan yang berkaitan dengan pengukuran variabel lain yang diperlukan.

c. Memiliki informasi mengenai $P B V, R O A, D A R$ dan $D P R$.

d. Memiliki data keuangan, PBV, ROA, DAR dan DPR yang tidak minus (merugi) pada setiap tahun nya.

Adapun kriteria purposive sampling diatas, maka data yang menjadi sampel dalam penelitian ini dapat dilihat pada tabel 2.1 sebagai berikut :

Tabel 2.1 Purposive Sampling

\begin{tabular}{|l|c|c|}
\hline \multicolumn{1}{|c|}{ Keterangan } & $\begin{array}{c}\text { Jumlah Yang Tidak } \\
\text { Tersedia Data }\end{array}$ & $\begin{array}{c}\text { Jumlah Yang Tersedia } \\
\text { Data }\end{array}$ \\
\hline Jumlah Emiten & - & 16 \\
\hline $\begin{array}{l}\text { Data PBV, ROA, } \\
\text { DAR dan DPR }\end{array}$ & 12 & 4 \\
\hline Jumlah Sampel Akhir & & 4 \\
\hline
\end{tabular}

Berdasarkan tabel 1.1 purposive sampling maka yang masuk menjadi sampel dalam penelitian ini adalah sebanyak 4 perusahaan sektor perkebunan. Nama-nama perusahaan yang masuk menjadi sampel penelitian sebagai berikut:
a. PT. Astra Argo Lestari Tbk. (AALI)
b. PT. Jaya Agra Wattie Tbk. (JAWA)
c. PT. PP London Sumatra Indonesia Tbk. (LSIP) 
d. PT. Salim Ivomas Pratama Tbk. (SIMP)

\section{Metode Pengumpulan data}

Dalam melakukan penelitian ini menggunakan data sekunder yang berupa laporan-laporan yang dipublikasikan oleh Bursa Efek indonesia. Melakukan studi pustaka (library research) yaitu dengan mengumpulkan data pen dukung berupa literatur jurnal penelitian terdahulu serta laporan-laporan yang dipublikasikan untuk mendapatkan permasalahan yang akan diteliti. melalui Indonesia,melalui Capital Market Directory (ICDM) dan www.idx.co.id.

\section{Metode Analisis Data} berikut:

Dalam penelitian ini, penelitian menggunakan metode analisa sebagai

a. Deskriptif Kualitatif

Yaitu suatu metode yang berfungsi untuk membuat gambaran fakta-fakta yang ada dilapangan berdasarkan teori-teori yang ada dalam literatur yang ada kaitanya dengan penelitian ini.

b. Deskriptif Kuantitatif

Yaitu suatu metode yang berfungsi untuk membuat gambaran secara matematis berdasarkan perhitungan-perhitungan dari hasil penelitian menggunakan SPSS 22.

\section{HASIL DAN PEMBAHASAN}

1. Pengaruh Keputusan Investasi (ROA), Keputusan Pendanaan (DAR) dan Kebijakan Deviden (DPR) secara simultan dan parsial terhadap Nilai Perusahaan (Y)

Berdasarkan hasil penelitian yang telah dilakukan, maka dapat diambil beberapa kesimpulan pada pengujian pengaruh Keputusan Investasi (ROA), Keputusan Pendanaan (DAR), dan Kebijakan Deviden (DPR) terhadap Nilai Perusahaan (Y) pada Sektor Perkebunan yang terdaftar di Bursa Efek Indonesia periode 2011-2014 sebagai berikut:

Terdapat pengaruh signifikan secara simultan antara ROA, DAR, dan DPR terhadap Nilai Perusahaan (PBV) pada Sektor Perkebunan yang terdaftar di Bursa Efek Indonesia periode 2011-2014. Hal ini ditunjukkan dengan $F_{\text {hitung }}$ besar dari $F_{\text {tabel }}(18,190>3,49)$. Dengan membandingkan besarnya angka taraf signifikan (sig) penelitian sebesar 0,05 maka 0,000 < 0,05 sehingga dapat dikatakan bahwa ada pengaruh positif antara ROA $\left(\mathrm{X}_{1}\right)$, DAR $\left(\mathrm{X}_{2}\right)$, dan DPR $\left(\mathrm{X}_{3}\right)$ secara bersama-sama terhadap PBV (Y) pada Sektor Perkebunan yang terdaftar di Bursa Efek Indonesia periode 2011-2014.

Berdasarkan dari perbandingan hasil penelitian yang dilakukan terdahulu pada skripsi Singgih tahun 2013 pada perusahaan industri motomotive berpengaruh positif dan signifikan dan skripsi Mardiah tahun 2012 pada perusahaan manufaktur berpengaruh positif dan signifikan. Sejalan dengan penelitian yang dilakukan sekarang pada perusahaan sektor perkebunan. Mengingat terdapat hasil yang sama dari penelitian terdahulu, maka penelitian ini sejalan.

Sedangkan secara parsial hanya DPR yang berpengaruh signifikan terhadap Nilai Perusahaan (PBV) hal ini ditunjukkan dengan nilai thitung variabel DPR $\left(\mathrm{X}_{3}\right)$ sebesar 2,798 dan $\mathrm{t}_{\text {tabel }}$ sebesar 2,179 dari hasil perbandingan maka dapat diketahui $t_{\text {hitung }}$ lebih besar $t_{\text {tabel }}(2,798>2,179)$ dengan nilai 
signifikan sebesar 0,000. Maka $\mathrm{H}_{\mathrm{o}}$ di tolak dan $\mathrm{H}_{\mathrm{a}}$ diterima, artinya berpengaruh positif secara signifikan terhadap variabel Nilai Perusahaan (PBV) pada Sektor Perkebunan yang terdaftar di Bursa Efek Indonesia periode 20112014.

Secara parsial tidak terdapat pengaruh variabel ROA terhadap Nilai Perusahaan hal ini ditunjukkan dengan nilai $t_{\text {hitung variabel } \mathrm{ROA}}\left(\mathrm{X}_{1}\right)$ sebesar 1,255 dan $t_{\text {tabel }}$ sebesar 2,179 dari hasil perbandingan maka dapat diketahui $\mathrm{t}_{\text {hitung }}$ lebih kecil dari $\mathrm{t}_{\text {tabel }}(1,255<2,179)$ dengan nilai signifikan sebesar 0,233. Maka $\mathrm{H}_{\mathrm{o}}$ diterima dan $\mathrm{H}_{\mathrm{a}}$ ditolak, artinya tidak berpengaruh signifikan terhadap Nilai Perusahaan (Y) pada Sektor Perkebunan yang terdaftar di Bursa Efek Indonesia periode 2011-2014.

Secara parsial tidak terdapat pengaruh yang signifikan variabel DAR $\left(\mathrm{X}_{2}\right)$ terhadap Nilai Perusahaan (Y). Hal ini ditunjukan dengan nilai $t_{\text {hitung variabel }}$ DAR $\left(\mathrm{X}_{2}\right)$ sebesar -0,506 dan $\mathrm{t}_{\text {tabel }}$ sebesar 2,179 dari hasil perbandingan, maka dapat diketahui thitung lebih kecil dari $t_{\text {tabel }}(-0,506<2,179)$ dengan nilai signifikan sebesar 0,622. Maka $\mathrm{H}_{\mathrm{o}}$ diterima dan $\mathrm{H}_{\mathrm{a}}$ ditolak, artinya tidak berpengaruh signifikan terhadap Nilai Perusahaan (Y) pada Sektor Perkebunan yang terdaftar di Bursa Efek Indonesia pada periode 2011-2014.

Berdasarkan dari perbandingan hasil penelitian yang dilakukan terdahulu tidak konsisten dengan penelitian yang dilakukan sekarang. Pada penelitian terdahulu skripsi Singgih tahun 2013 pada perusahaan industri otomotive berpengaruh positif secara parsial antara PER $\left(\mathrm{X}_{1}\right)$, ROA $\left(\mathrm{X}_{2}\right)$, DPR $\left(\mathrm{X}_{3}\right)$ terhadap PBV (Y). Pada penelitian terdahulu skripsi Mardiah tahun 2012 pada perusahaan manufaktur yang berpengaruh hanya ROA $\left(\mathrm{X}_{2}\right)$ dan DPR $\left(\mathrm{X}_{3}\right)$ terhadap PBV (Y). Sedangkan dengan penelitian yang dilakukan sekarang pada perusahaan sektor perkebunan hanya DPR $\left(\mathrm{X}_{3}\right)$ yang berpengaruh terhadap PBV (Y).

2. Variabel manakah yang dominan perpengaruh terhadap Nilai Perusahaan (Y)

Berdasarkan pengujian hipotesis secara parsial hanya DPR yang dominan berpengaruh signifikan terhadap Nilai Perusahaan (PBV) hal ini ditunjukkan dengan nilai thitung variabel DPR $\left(\mathrm{X}_{3}\right)$ sebesar 2,798 dan tabel sebesar 2,179 dari hasil perbandingan maka dapat diketahui $t_{\text {hitung }}$ lebih kecil $t_{\text {tabel }}(2,798>2,179)$ dengan nilai signifikan sebesar 0,000 . Maka $\mathrm{H}_{\mathrm{o}}$ di tolak dan $\mathrm{H}_{\mathrm{a}}$ diterima, artinya berpengaruh positif secara signifikan terhadap variabel Nilai Perusahaan (PBV) pada Sektor Perkebunan yang terdaftar di Bursa Efek Indonesia periode 2011-2014.

\section{Simpulan}

\section{SIMPULAN DAN SARAN}

Berdasarkan hasil penelitian dan pembahasan, maka dapat ditarik kesimpulan sebagai berikut :

1. Pengaruh Keputusan Investasi (ROA), Keputusan Pendanaan (DAR), dan Kebijakan Deviden (DPR) terhadap Nilai Perusahaan (Y) pada Sektor Perkebunan yang terdaftar di Bursa Efek Indonesia periode 2011-2014.

a. Pengaruh Secara Simultan

Terdapat pengaruh signifikan secara simultan antara ROA, DAR, dan DPR terhadap Nilai Perusahaan (PBV) pada Sektor Perkebunan yang terdaftar di Bursa Efek Indonesia periode 2011-2014. Hal ini ditunjukkan dengan $F_{h i t u n g}$ 
besar dari $F_{\text {tabel }}(18,190>3,49)$. Dengan membandingkan besarnya angka taraf signifikan (sig) penelitian sebesar 0,05 maka $0,000<0,05$ sehingga dapat dikatakan berpengaruh signifikan antara ROA $\left(\mathrm{X}_{1}\right)$, DAR $\left(\mathrm{X}_{2}\right)$, dan DPR $\left(\mathrm{X}_{3}\right)$ secara bersama-sama terhadap PBV (Y) pada Sektor Perkebunan yang terdaftar di Bursa Efek Indonesia periode 2011-2014.

b. Pengaruh Secara Parsial

1) Secara parsial hanya DPR yang berpengaruh signifikan terhadap Nilai Perusahaan (PBV) hal ini ditunjukkan dengan nilai $t_{\text {hitung variabel DPR }}$ $\left(\mathrm{X}_{3}\right)$ sebesar 2,798 dan $t_{\text {tabel }}$ sebesar 2,179 dari hasil perbandingan maka dapat diketahui $t_{\text {hitung }}$ lebih kecil $t_{\text {tabel }}(2,798>2,179)$ dengan nilai signifikan sebesar 0,000. Maka $\mathrm{H}_{\mathrm{o}}$ di tolak dan $\mathrm{H}_{\mathrm{a}}$ diterima, artinya berpengaruh positif secara signifikan terhadap variabel Nilai Perusahaan (PBV) pada Sektor Perkebunan yang terdaftar di Bursa Efek Indonesia periode 2011-2014.

2) Secara parsial tidak terdapat pengaruh variabel ROA terhadap Nilai Perusahaan hal ini ditunjukkan dengan nilai thitung variabel ROA $\left(\mathrm{X}_{1}\right)$ sebesar 1,255 dan $t_{\text {tabel }}$ sebesar 2,179 dari hasil perbandingan maka dapat diketahui thitung lebih kecil dari $t_{\text {tabel }}(1,255<2,179)$ dengan nilai signifikan sebesar 0,233 . Maka $\mathrm{H}_{\mathrm{o}}$ diterima dan $\mathrm{H}_{\mathrm{a}}$ ditolak, artinya tidak berpengaruh signifikan terhadap Nilai Perusahaan (Y) pada Sektor Perkebunan yang terdaftar di Bursa Efek Indonesia periode 2011-2014.

3) Secara parsial tidak terdapat pengaruh yang signifikan variabel DAR $\left(\mathrm{X}_{2}\right)$ terhadap Nilai Perusahaan (Y). Hal ini ditunjukan dengan nilai $t_{\text {hitung }}$ variabel DAR $\left(\mathrm{X}_{2}\right)$ sebesar -0,506 dan $t_{\text {tabel }}$ sebesar 2,179 dari hasil perbandingan, maka dapat diketahui $t_{\text {hitung }}$ lebih kecil dari $t_{\text {tabel }}(-0,506<$ 2,179) dengan nilai signifikan sebesar 0,622. Maka $\mathrm{H}_{\mathrm{o}}$ diterima dan $\mathrm{H}_{\mathrm{a}}$ ditolak, artinya tidak berpengaruh signifikan terhadap Nilai Perusahaan (Y) pada Sektor Perkebunan yang terdaftar di Bursa Efek Indonesia pada periode 2011-2014.

4) Berdasarkan dari perbandingan hasil penelitian yang dilakukan terdahulu tidak konsisten dengan penelitian yang dilakukan sekarang. Pada penelitian terdahulu skripsi Singgih tahun 2013 pada perusahaan industri motomotive berpengaruh positif secara parsial antara PER $\left(\mathrm{X}_{1}\right)$, ROA $\left(\mathrm{X}_{2}\right)$, DPR $\left(\mathrm{X}_{3}\right)$ terhadap PBV $(\mathrm{Y})$. Pada penelitian terdahulu skripsi Mardiah tahun 2012 pada perusahaan manufaktur yang berpengaruh hanya ROA $\left(\mathrm{X}_{2}\right)$ dan DPR $\left(\mathrm{X}_{3}\right)$ terhadap PBV $(\mathrm{Y})$. Sedangkan dengan penelitian yang dilakukan sekarang pada perusahaan sektor perkebunan hanya DPR $\left(\mathrm{X}_{3}\right)$ yang berpengaruh terhadap PBV $(\mathrm{Y})$.

2. Nilai Koefisien determinasi adalah sebesar 0,820 hal itu berarti bahwa variasi perusahaan dipengaruhi oleh perubahan $\operatorname{ROA}\left(\mathrm{X}_{1}\right)$, DAR $\left(\mathrm{X}_{2}\right)$ dan $\operatorname{DPR}\left(\mathrm{X}_{3}\right)$ sebesar $82 \%$. Jadi besarnya pengaruh ROA, DAR, dan DPR terhadap DPR/Nilai Perusahaan adalah sebesar $82 \%$. Sedangkan sisanya sebesar $18 \%$ dipengaruhi oleh faktor lain diluar penelitian ini.

3. Variabel yang dominan berpengaruh terhadap Nilai Perusahaan (Y) yaitu :

Berdasarkan pengujian hipotesis secara parsial hanya DPR yang dominan berpengaruh signifikan terhadap Nilai Perusahaan (PBV) hal ini ditunjukkan dengan nilai thitung variabel DPR $\left(\mathrm{X}_{3}\right)$ sebesar 2,798 dan $\mathrm{t}_{\text {tabel }}$ sebesar 2,179 dari hasil perbandingan maka dapat diketahui $t_{\text {hitung lebih kecil } t_{\text {tabel }}(2,798>2,179)}$ dengan nilai signifikan sebesar 0,000. Maka $\mathrm{H}_{\mathrm{o}}$ di tolak dan $\mathrm{H}_{\mathrm{a}}$ diterima, 
artinya berpengaruh positif secara signifikan terhadap variabel Nilai Perusahaan (PBV) pada Sektor Perkebunan yang terdaftar di Bursa Efek Indonesia periode 2011-2014.

\section{Saran}

Saran yang dapat peneliti sampaikan dalam penelitian ini adalah sebagai berikut :

1. Bagi investor ataupun calon investor yang akan menanamkan investasinya agar dapat menganalisis laporan keuangan perusahaan sebelum menanamkan investasi, sedangkan yang memiliki investasi pada sektor Perkebunan yang Terdaftar di Bursa Efek Indonesia dapat mempertimbangkan Deviden Payout Ratio (DPR) Karena dalam penelitian ini Deviden Payout Ratio (DPR) mempunyai pengaruh signifikan secara simultan maupun parsial terhadap Price Book Value / Nilai Perusahaan, maka manajemen perlu tetap menjaga rasio ini karena berkaitan dengan kebijakan deviden.

2. Bagi peneliti selanjutnya perlu memilih perusahaan dibidang lain untuk memperoleh hasil yang lebih valid. Diharapkan menambah rasio keuangan lainnya sebagai variabel independen, karena sangat dimungkinkan rasio keuangan lain yang tidak dimasukkan dalam penelitian ini berpengaruh terhadap Nilai Perusahaan.

\section{DAFTAR PUSTAKA}

Brigham, 2009, Pengantar Manajemen Keuangan, PT. Pelita Ilmu, Jakarta.

Fahmi, Irham, 2013, Analisis Laporan Keuangan, ALFABETA, Bandung.

Hanafi Mamduh, 2011, Analisis Laporan Keuangan, UPP STIM YKPN, Yogyakarta.

Hidayat, 2010, Manajemen Keuangan dan Akutansi Untuk. Eksekutif Perusahaan,

PT. Raja Grafindo Persada, Jakarta.

http://www.idx.co.id

Husnan, Suad, 2014, Dasar-Dasar Manajemen Keuangan, Akademi Manajemen Perusahaan YPKN, Yogyakarta.

Pawestri, 2006, Accounting Analysis Journal, Universitas Negeri Semarang.

Pudjiastuti dan Husnan, 2006, Keputusan Investasi, PT. Gramedia, Jakarta.

Rohman, 2012, Manajemen Keuangan, PUSTAKA, Bandung.

Pengaruh Keputusan Investasi, Keputusan Pendanaan, dan Kebijakan Deviden terhadap Nilai Perusahaan pada Sektor Perkebunan yang Terdaftar di Bursa Efek Indonesia Periode 2011-2014 